\title{
Characterisation of the Amaranth Genetic Resources in the Czech Gene Bank
}

\author{
Dagmar Janovská1, Petra Hlásná Čepková ${ }^{2}$ and Mária Džunkováa \\ ${ }^{1}$ Department of Gene Bank, Crop Research Institute \\ ${ }^{2}$ Department of Crop Sciences and Agroforestry in Tropics and Subtropics \\ Institute of Tropics and Subtropics, Czech University of Life Sciences Prague \\ ${ }^{3}$ Department of Genomics and Health, \\ Centre for Public Health Research (CSISP), Valencia \\ ${ }^{1,2}$ Czech Republic \\ ${ }^{3}$ Spain
}

\section{Introduction}

The human species depends on plants. These constitute the basis for food, supply most of our needs (including clothes and shelter) and are used in industry for manufacturing fuels, medicines, fibres, rubber and other products. However, the number of plants that humans use for food is minimal, compared to the number of species existing in nature. Only 30 crops, the most outstanding of which are rice, wheat and maize, provide $95 \%$ of the calories needed in the human diet (Jaramillo \& Baena, 2002). However, agricultural biodiversity is in sharp decline due to the effects of modernisation, such as concentration on a few competitive species and changes in diets. Since the beginning of agriculture, the world's farmers have developed roughly 10000 plant species for use in food and fodder production. Today, only 150 crops feed most of the world's population, and just 12 crops provide $80 \%$ of dietary energy from plants, with rice, wheat, maize and potato providing $60 \%$. It is estimated that about three quarters of the genetic diversity found in agricultural crops have been lost over the past century, and this genetic erosion continues (EC, 2007).

Humans need to add to their diet those crops of high yield and quality that can adapt to environmental conditions and resist pests and diseases. Advantage must be taken of native and exotic species, with nutritional or industrial potential, or new varieties must be developed. Improving crops, however, requires reserves of genetic materials whose conservation, management and use have barely begun to receive the attention that they deserve. Humans take advantage of plant genetic resources in as much as they are useful to us, which means that we must understand them, and know how to manage, maintain and use them rationally (Jaramillo \& Baena, 2002). Information on genetic diversity and relationships within and among crop species and their wild relatives is essential for the efficient utilization of plant genetic resource collections for the efficient explanation of taxonomic relationships (Chan \& Sun, 1997; Drzewiecki et al., 2003).

Amaranthus L. is a genus from Amaranthaceae family probably originated in America. This genus contains approximately 70 species of worldwide distribution including pigweeds, 
waterhemps, and grain amaranths (Sauer, 1967). The origin of various species of cultivated amaranths is not easy to trace because wild ancestors are pantropical cosmopolitan weeds (Espitia-Rangel, 1994). For human consumption there are cultivated grain amaranths A.caudatus, A. cruentus and A. hypochondriacus and vegetable amaranths - mainly A.dubius, A.tricolor and A.cruentus. Grain amaranths are crop species of New World origin; A. caudatus from Andean Peru and Ecuador, A. cruentus and A. hypochondriacus from Mexico and Central America (Sauer, 1950; Drzewiecki, 2001). Nowadays, the grain amaranths are cultivated from the temperate to tropical zone and the vegetable amaranths mainly in the South Africa and South Asia (Jarošova et al., 1997).

Amaranths are very promising crops. The main reasons could be content of protein, fat and active substances. The content of seed protein is in the range $13-18 \%$ with very good balanced amino acids. The lysine content is relatively high in the comparison with common cereals. The content of crude proteins in leaves is from 27 to $49 \%$ in d.m. what is more than in the leaves in the spinach (Segura-Nieto, 1994). Amaranths have comparable or higher amounts of essential amino acids as whole egg protein (Drzewiecki et al., 2003). The fat content is in the range $0.8-8.0 \%$. The linoleic acid is the predominant fatty acid, with lesser amount of oleic and palmitic acids. The oil also contains squalene, precursor of cholesterol, which is used in the cosmetics and as a penetrant and lubricant (Becker, 1994). Many compounds and extracts from amaranths possessed anti-diabetic, anti-hyperlipidemic, spermatogenic and anti-cholesterolemic effects (Sangameswaran \& Jayakar, 2008; Girija et al., 2011), antioxidant and antimicrobial activity (Alvarez-Jubete et al., 2010; Tironi\&Anon, 2010). Many consumers purchase amaranth because they want a wheat- and gluten-free product, like the nutritional profile of amaranth, or enjoy "exotic" foods in their diet (Brenner et al., 2000). Amaranth can be used also as a feed for pigs, hens, etc. (Pisarikova et al., 2005). From the cultivation point of view, amaranth is interesting for its heat and drought resistance and very low susceptibility to diseases and pests (Barba de la Rosa, 2009). Considering its agronomic importance, attention should be given to the cultivation, conservation, and sustainable utilization of this promising crop (Ray \& Roy, 2009).

Unfortunately, amaranths are also very harmful weeds spread in all over the world. Weedy Amaranthus species (pigweeds) have been and continue to be a major problem in agronomic production. The weed amaranth A. retroflexus is considered one of the world's worst weeds. A major contributor to the noxious nature of these weedy species is their ability to efficiently adapt to the changes in agricultural management practices that are specifically designed to control and prevent colonization. For example, numerous populations of pigweeds have evolved herbicide resistance (Drzewiecki, 2001; Rayburn et al., 2005).

In the Czech Republic the cultivation of amaranth was introduced in the early 1990s (Michalova 1999; Moudry et al. 1999) and the collection of amaranth genetic resources was established in 1993 in the Czech Gene Bank. Due to the very positive effects on the human health, we try to find out genotypes suitable for the Czech conditions with utilization in the Czech cuisine. On the Czech market, there is very popular food made from amaranth flour such as chips, cookies, and breakfast cereals, etc. However, all amaranth seeds are imported into the Czech Republic from other countries. The demand for vegetable amaranth is also increasing. Presently, in the Gene Bank, there are stored 103 evaluated accessions. In the working collection (in the different stages of evaluations), there are more than 30 accessions. Seed samples of amaranth are obtained from other gene banks, universities, private subjects 
or from collecting missions from all over the world. It corresponds with international agreements and with The Czech National Programme on Conservation and Utilization of Plant Genetic Resources and Agro-biodiversity. For maintenance and utilization of plant genetic resources of amaranths, it is very important to know them from all sides. Genetic resources studies are oriented on evaluation of the most important biological characters, with respect to the effective utilization of genetic resources in breeding and agricultural practice. Good characterization and evaluation of genetic resources under conditions similar to those of their origin can provide breeders and users with valuable information on effective utilization of genetic resources for the breeding programmes and utilization. Characterization of genetic resources is focused mainly on morphological characters. The evaluation consists of data on plant growth and development, characteristics of plant stand, analysis of yield elements, etc. (Dotlačil et al., 2001). First steps of evaluations after seed samples receiving, are field evaluations. The phenological and morphological evaluation such as length of vegetation, plant height, length of inflorescence, colour of inflorescence, type of inflorescence, etc., is performed during vegetation. The length of vegetation is very important for amaranth cultivation in the Czech Republic, because many of the amaranths genotypes are sensitive to day-length. They remain in the vegetative period for a long time and create seeds after day-shortening (NRC, 1984). In the Czech Republic, they flower in the second half of September. Because the early frost, they cannot mature their seeds.

For genetic improvement of Amaranthus, germplasm collections will play a key role as well. However, only limited information is available on intra- and inter-specific genetic diversity and relationships within Amaranthus germplasm collections (Chan \& Sun, 1997). In spite of the fact that it has been the object of many studies, the genus Amaranthus is still poorly understood, being widely considered as a "difficult" genus. Currently, the taxonomic problems are far from being clarified especially because of the widespread nomenclatural disorder caused chiefly by repeated misapplication of names (Costea et al., 2001) which is shown in Table 1. Due to variation of morphological characters, accurate classification of amaranth genetic resources is not always possible (Transue et al., 1994).

For preliminary identification of Amaranthus species, the useful tool can be the number, thickness, orientation and density of branches in inflorescences. The flowers are arranged in small and very contracted cymes, which are agglomerated, axillary and additionally arranged in racemose or spiciform terminal, large and complex synflorescences. Although extremely variable, there is usually a tendency towards a morphological "type" (Costea et al., 2001).

The colour of the seeds is commonly dark-brown to blackish, or whitish-yellowish, sometimes with reddish nuances at the species cultivated as cereals. Many cultivars of $A$. caudatus have pink cotyledons visible through the seed coat. The colour may be uniform or not, in the last case usually with the marginal zone paler. Weedy species and species used as a vegetable have mostly black or dark seeds (Costea et al., 2001; Jarošová et al., 1997; Das, 2011).

Many species of the genus are greatly affected by environmental factors (nutritional elements, water availability, light conditions, injurious factors, etc. exhibiting a great morphological variability with little taxonomic significance (Costea et al., 2001). All the above mentioned characteristics are useful for the taxonomy of the genus but difficult to use 
for the current identification of taxa (Costea et al., 2001). Also it is dependent on the cultivation in the field conditions. In the case of a gene bank, when seed samples are received, it is necessary to sow them in the field conditions for the morphological and phenological evaluations. But in the case of weedy species, it would be better to know, if the samples are not harmful weeds. We need to exclude weeds from our collection.

Many different methods of identification have been used for evaluation of amaranth diversity. RAPD analysis was successful in the investigation of the relationships of four $A$. hypochondriacus varieties (Barba de la Rosa et al., 2009). AFLP markers were successfully used to determine species what demonstrated taxonomic ambiguity at the basic morphologic level (Costea et al., 2006). Other methods such as ITS, ISSR and isozyme profile were used to get exhaustive view of interrelationship and relative closeness among amaranth species (Das, 2011; Xu \& Sun, 2001). Also other methods such as electrophoresis profiles of proteins have been successfully used to clarify the taxonomy of many families. There was published, that electrophoresis can also be used to characterize the seed protein profiles of species and cultivars, compare cultivars of different geographical origin, and provide taxonomically useful descriptors that are substantially free from environmental influence. This method is rapid, relatively cheap, largely unaffected by the growth environment and eliminate to grow plant to maturity (Juan et al., 2007; Jugran et al., 2010). Drzewiecki (2001) used SDS PAGE of urea-soluble proteins of amaranth seeds for distinguishing both - species and their cultivars. Samples of seven species were divided into three groups by protein patterns according to similarity. According to solubility, Osborne (1907) divided proteins into four classes: albumins soluble in water, globulins soluble in high salt concentration, prolamins soluble in aqueous alcohol and glutelins soluble in acid or alkaline solutions (Segura-Nieto et al., 1994). The division into four protein fractions brings the possibility to see the differences among seed samples more clearly. The first general characterization of the protein fraction spectra of amaranth species was performed by Gorinstein et al. (1991) and Drzewiecki et al. (2003). Finally, Dzunkova et al. (2011) set up the methodology for clear identification of the amaranth species using glutelin protein fraction. The washing off water, salt- and alcohol- soluble proteins in protein fraction separation process makes polymorphic peaks of amaranth glutelins to be distinguished very easily.

SDS PAGE has been the traditional method for analysing glutenin subunit composition of wheat, but the procedure is slow, laborious and non-quantitative. The chip microfluidic technology, based on capillary electrophoresis, provides new opportunities in analysis of wheat HMW-GSs. This procedure is rapid, simple to operate, enabling automatic and immediate quantitative interpretation. Other advantages over traditional gel electrophoresis are lower sample and reagent volume requirements and a reduced exposure to hazardous chemicals (Bradova \& Matejova, 2008).

In this work, we focused on evaluation for precise determination of amaranth genetic resources in the Czech Gene Bank. One of our aims was to separate amaranth species according to protein patterns and to verify our hypothesis of different protein fraction pattern based on species and variety. We compared spectra of storage proteins and their fractions of wild weedy and cultivated species of amaranths and verified the suitability of this method for species identification in our collection. 


\begin{tabular}{|c|c|}
\hline Latin name & Synonyms \\
\hline Amaranthus caudatus L. ${ }^{1}$ & $\begin{array}{l}\text { Amaranthus caudatus subsp. caudatus } \\
\text { Amaranthus caudatus subsp. mantegazzianus }\end{array}$ \\
\hline $\begin{array}{l}\text { Amaranthus caudatus subsp. } \\
\text { caudatus }^{1}\end{array}$ & $\begin{array}{l}=\text { Amaranthus alopecurus Hochst. ex A. Br. \& } \\
\text { Bouche } \\
=\text { Amaranthus abyssinicus hort. ex L.H. Bailey. } \\
=\text { Amaranthus caudatus subsp. saueri Jehlik } \\
=\text { Amaranthus caudatus L. } \\
=\text { Amaranthus maximus Mill. } \\
=\text { Chenopodium millmi J.T. del Granado } \\
=\text { Amaranthus caudatus var. alopecurus Moq. }\end{array}$ \\
\hline $\begin{array}{l}\text { Amaranthus caudatus subsp. } \\
\text { mantegazzianus }^{1}\end{array}$ & $\begin{array}{l}=\text { Amaranthus edulis Spegazz. } \\
=\text { Amaranthus mantegazzianus Passer. }\end{array}$ \\
\hline Amaranthus cruentus L. ${ }^{1}$ & $\begin{array}{l}=\text { Amaranthus caudatusauct. } \\
=\text { Amaranthus paniculatus L. } \\
=\text { Amaranthus hybridus var. cruentus } \\
=\text { Amaranthus sanguineus L. } \\
=\text { Amaranthus hybridus 'paniculatus'. } \\
=\text { Amaranthus speciosus }\end{array}$ \\
\hline Amaranthus retroflexus L. ${ }^{1}$ & $\begin{array}{l}=\text { Amaranthus patulusauct. } \\
=\text { Amaranthus delilei Richter \& Loret }\end{array}$ \\
\hline Amaranthus hypochondriacus L. ${ }^{1}$ & $\begin{array}{l}\text { = Amaranthus chlorostachys var. erythrostachys } \\
\text { (Moq.) Aell. } \\
=\text { Amaranthus leucospermus S. Wats. } \\
=\text { Amaranthus leucocarpus S. Wats. } \\
=\text { Amaranthus hybridus convar. erythrostachys } \\
\text { (Moq.) Thell. ex Asch. \& Graebn. } \\
=\text { Amaranthus hybridus subsp. hypochondriacus (L.) } \\
\text { Thell. } \\
=\text { Amaranthus flavus L. } \\
=\text { Amaranthus frumentacea Buch.-Ham. } \\
=\text { Amaranthus chlorostachys var. leucocarpus (S. } \\
\text { Wats.) Aell. } \\
=\text { Amaranthus anardana Buch.-Ham. }\end{array}$ \\
\hline $\begin{array}{l}\text { Amaranthus cannabinus ( L. ) } \\
\text { J.D.Sauer }{ }^{2}\end{array}$ & Acnida cannabina L. \\
\hline \multicolumn{2}{|l|}{ Amaranthus deflexus L. ${ }^{2}$} \\
\hline $\begin{array}{l}\text { Amaranthus tuberculatus (Moq. ) } \\
\text { J.D.Sauer }{ }^{2}\end{array}$ & Acnida tuberculata Moq. \\
\hline
\end{tabular}

1according to Mansfeld'sEncyclopedia of Agricultural and Horticultural Crops (Hanelt\& IPGCPR, 2001) 2according to IPNI (2011)

Table 1. Synonyms of selected amaranth species 


\section{Materials and methods}

\subsection{Plant material}

For the evaluation there were used 46 amaranth genotypes from Crop Research Institute in Prague, Czech Republic (CRI) and from USDA, ARS, NCRPIS Iowa State University. In these samples, there were 6 accessions of wild weed and 40 of the cultivated species. The acronyms used for the wild species were as follows: De - A. deflexus, $\mathrm{Au}-A$. australis, $\mathrm{Wr}-A$. wrightii, Tu - A. tuberculatus, $\mathrm{Cn}-A$. cannabinus, $\mathrm{Re}-A$. retroflexus. The cultivated samples were evaluated in the field conditions in 2008 and 2009 according to the list of descriptors for amaranths created for purposes of the Czech Gene Bank. The morphological and phenological characters are evaluated according to List of Descriptors for amaranth created in the Czech Gene Bank. Following traits were evaluated in the field conditions:

- number of days from emergence to inflorescence observation,

- number of days from emergence to flowering,

- number of days from emergence to maturity.

The first two traits were assessed when $50 \%$ of plants were in this stage. The numbers of day from emergence to inflorescence observation and the numbers of days from emergence to flowering are important characters due to fact, that certain amaranth genotypes are sensitive to day-length. Maturity was estimated when $75 \%$ of the grains were mature. Plant height was measured from the soil surface to the top of the main stem in $\mathrm{cm}$. Length of inflorescence was measured from the downmost branch to the top of inflorescence of the main stem in $\mathrm{cm}$. Weight of thousand seeds (WTS) was weight of thousand seeds in $\mathrm{g}$.

\subsection{Total seed protein content and protein fractions content determination}

The measurements of total seed protein content and protein fraction content were performed by the Kjeldahl method (Czech state norm 56 0512-12) in Kjeltec automatic analyzer (Kjeltec 2300, Foss Tecator, Sweden) with the protein-nitrogen coefficient set to 6.025. Protein fractions (albumins, globulins, prolamins and total glutelins) were extracted according to the protocol developed for the wheat protein fraction separation by Dvoracek (2006) with some modifications. For the determination of protein fractions content was used $0.5 \mathrm{~g}$ of milled amaranth seeds. The protein fractions were extracted by adding $5 \mathrm{ml}$ of solvent (distilled water for albumins, $0.5 \mathrm{M} \mathrm{NaCl}$ for globulins, cold $60 \%$ ethanol for prolamins), vortexing and centrifuging by $10000 \times \mathrm{g}$ for 15 minutes (Universal 32R HettichCentrifugen, Germany). This procedure was repeated twice and the supernatants from each extraction were saved and poured together. In the case of prolamins, after first addition of solvent, tubes were vortexed and chilled to $4^{\circ} \mathrm{C}$ for 4 hours; after that the procedure was performed exactly as for albumins and globulins. The protein content of whole seed was also measured by milling $1 \mathrm{~g}$ of amaranth seeds. For the boiling in the automatic digestion system (2015lift, 2020 digestor, Foss Tecator, Denmark) were used $10 \mathrm{ml}$ from the obtained $15 \mathrm{ml}$ of each fraction extract. Into the each $250 \mathrm{ml}$ tube one catalyser tablet, $3.5 \mathrm{~g}$ of $\mathrm{K}_{2} \mathrm{SO}_{4}$ and $\mathrm{CuSO}_{4}$ mixture and $10 \mathrm{ml}$ of $\mathrm{H}_{2} \mathrm{SO}_{4}$ were added. In one tube was a blank sample. Tubes were let to boil to the temperature of $420^{\circ} \mathrm{C}$ for about $1 \mathrm{~h} 40 \mathrm{~min}$. After cooling for about $10 \mathrm{~min}, 75 \mathrm{ml}$ of distilled water was added. The content of glutelin and the residual nitrogen fraction was calculated as the difference between the content of the total seed protein and three measured fractions. 


\subsection{Electrophoresis of the proteins}

\subsubsection{Extraction of the total seed storage proteins}

Five different approaches to the extraction were tested for the development of the best extraction approach:

1. single seed extracted in $18 \mu \mathrm{l}$ of the extraction solution,

2. bulk of 10 seeds extracted in $50 \mu \mathrm{l}$ of the extraction solution,

3. bulk of 10 seeds extracted in $100 \mu l$ of the extraction solution,

4. bulk of 100 seeds extracted in $200 \mu$ l of the extraction solution,

5. bulk of 100 seeds extracted in $400 \mu$ l of the extraction solution.

Seed samples were crushed separately and mixed with extraction solution (consisted of $0.0625 \mathrm{M}$ Tris- $\mathrm{HCl} \mathrm{pH} 8.8,5 \%(\mathrm{w} / \mathrm{v})$ 2- mercaptoethanol, 2\% (w/v) SDS, 10\% (w/v) glycerol, $0.01 \%(\mathrm{w} / \mathrm{v})$ bromphenol blue) by vortexing (MS2 Minishaker, IKA, Germany) several times in $1.5 \mathrm{ml}$ tubes. Tubes were allowed to stand at $4{ }^{\circ} \mathrm{C}$ for three hours. After this extraction time, the tubes were centrifuged at $12000 \times \mathrm{g}$ for $15 \mathrm{~min}$ (Universal 32R HettichCentrifugen, Germany). After the replacement of the samples to the new tubes, the samples were heated in a boiling water bath for $2 \mathrm{~min}$.

Ten seeds from each variety were selected randomly, crushed and put into $2 \mathrm{ml}$ micro tube. The protein fractions were extracted by adding $100 \mu \mathrm{l}$ of solvent (distilled water for albumins, $0.5 \mathrm{M} \mathrm{NaCl}$ for globulins, cold $60 \%$ ethanol for prolamins), vortexing and centrifuging by $10000 \times \mathrm{g}$ for 15 minutes (Universal 32R HettichCentrifugen, Germany). This procedure was repeated twice but the supernatants of the second and third wash were always discarded. In the case of prolamins, after first addition of solvent, tubes were vortexed and chilled to $4^{\circ} \mathrm{C}$ for 4 hours; after that the procedure was performed as in the case of albumins and globulins. Tubes containing protein fractions extract and the seed pellets (glutelins) were freezed to $-25^{\circ} \mathrm{C}$. After the supernatant in the tubes became solid, the top of the tubes was perforated by a needle to form small holes what serve to prevent the loss of the sample by lyofilisation. The lyofilisation was performed by freeze dryer (Christ, Germany) during $24 \mathrm{~h}$ at $-58^{\circ} \mathrm{C}$ and $0.018 \mathrm{mBar}$. The lyophilized solid samples were mixed with $100 \mu \mathrm{l}$ extraction solution (consisted of $0.0625 \mathrm{M}$ Tris- $\mathrm{HCl} \mathrm{pH} \mathrm{8.8,5 \%} \mathrm{(w/v)} \mathrm{2-}$ mercaptoethanol, $2 \%(\mathrm{w} / \mathrm{v})$ SDS, $10 \%(\mathrm{w} / \mathrm{v})$ glycerol, $0.01 \%(\mathrm{w} / \mathrm{v})$ bromphenol blue) by vortexing several times in $1.5 \mathrm{ml}$ tubes. Tubes were allowed to stand at $4{ }^{\circ} \mathrm{C}$ for three hours. After this extraction time, the tubes were centrifuged at $12000 \times \mathrm{g}$ for $15 \mathrm{~min}$. The supernatants were put into new tubes and heated in boiling water for $2 \mathrm{~min}$.

\subsubsection{Protein separation by SDS PAGE}

The amaranth protein extracts were separated in conditions of discontinuous electrophoresis (SDS-PAGE) according to Laemmli (1970) 4\% stacking gel of pH 6.8, 10\% separation gel of $\mathrm{pH} 8.8$ on the polyacrylamide gels of the size $180 \times 160 \times 0.75 \mathrm{~mm}$.

On the gel was loaded:

- $15 \mu \mathrm{l}$ of the single seed sample,

- $\quad 20 \mu \mathrm{l}$ of the 10 seed bulk, 100 seed bulk and all the protein fraction samples,

- $\quad 7 \mu$ l of the protein marker: SigmaMarker Wide Range (MW 6,500-200,000). 
The electrophoresis was performed on $90 \mathrm{~mA}(45 \mathrm{~mA} /$ gel) and let to run for about 4 hours. The gels were stained with a solution of $0.1 \%(\mathrm{w} / \mathrm{v})$ Coomasie Brilliant Blue (CBB) R250, $50 \%(\mathrm{w} / \mathrm{v})$ methanol, $10 \%$ acetic acid, $0.02 \%(\mathrm{w} / \mathrm{v})$ bromphenol blue salt for 1 day and destained with a solution of $25 \%(\mathrm{w} / \mathrm{v})$ denatured alcohol and 3.5\% (w/v) acetic acid, what lasted also 1 day. Gels were preserved in solution: $45 \%(\mathrm{w} / \mathrm{v})$ denatured alcohol, $3 \%(\mathrm{w} / \mathrm{v})$ glycerol for 2 hours, then dried and stored into cellophane sheets. The whole procedure including the test of the different extraction concentrations, the protein fraction separation procedure and the electrophoresis was repeated for the control of the correct experiment performance.

\subsubsection{Chip electrophoresis}

All the extracted protein fraction samples were analyzed by chip capillary electrophoresis using commercial Experion Pro260 Analysis Kit for 10 Chips and the Experion automated electrophoresis system (Bio-Rad Laboratories, USA) for protein quantification according to the manufacturer's instructions. Experion automated electrophoresis station performs automatically all the steps of the gel-based electrophoresis (samples separation, staining, destaining, imaging, band detections, and data analysis).

\subsection{Statistical analysis}

For the statistical evaluation of morphological traits, analysis of variance (ANOVA) and the Tukey HSD test were used (software -Statistica 7.0 CZ). In the case of protein fraction proportion in accessions with different seed colour, the basic statistics of $\mathrm{R}$ statistics 2.10 .0 software were used for calculation of mean $\mathrm{x}$, standard deviation sx and p-values (adjusted by Holm correction, two sided Welch Two Sample t-test used).

The SDS-PAGE spectra of total seed storage proteins and protein fractions were compared and confronted with the spectra of the chip capillary electrophoresis. The bands in the spectra were analyzed regarding the positions of the bands and also the relative intensity of the bands. The intensity of the bands was analyzed individually for each sample considering the intensity of the internal markers of the chip electrophoresis and the general intensity of all the bands in the sample. The intensity of the bands was expressed as the relative protein concentration measured by chip capillary electrophoresis what was the multiplication of numbers $0,1,2,3$ used in our statistics (0- no band, 1- light band, 2 - medium intensity band, 3 - dark band). The spectra expressed as the numerical values were analyzed by $R$ statistics 2.10 .0 software. The relationships between accessions were expressed by Pearson correlation using single linkage. The hierarchical clustering dendrogram was cut the level of correlation 0.99 to show the well defined clusters.

\section{Results and Discussion}

\subsection{Morphological and phenological evaluation}

Mean data of morphological and phenological evaluations of amaranth are shown in table 2 and 3. From our long-term observations, genotypes with number of days from emergence to flowering higher than 100 days likely does not mature before early frost in autumn. The vegetation period in evaluated collection ranged from $92 \pm 0.00$ to $163.00 \pm 0.00$ days. Also height of plants in maturity and length of inflorescence is a very useful character. Both are 


\begin{tabular}{|c|c|c|c|}
\hline & $\begin{array}{c}\text { From emergence to inflorescence } \\
\text { observation (days) }\end{array}$ & $\begin{array}{c}\text { From emergence to } \\
\text { flowering (days) }\end{array}$ & $\begin{array}{c}\text { From emergence to } \\
\text { maturity (days) }\end{array}$ \\
\hline Genotype & Mean \pm SD & Mean $\pm S D$ & Mean \pm SD \\
\hline 6 & $56.00 \pm 1.41^{\mathrm{abc}}$ & $72.00 \pm 7.07$ bcdef & $107.00 \pm 16.97 \mathrm{ab}$ \\
\hline 11 & $51.50 \pm 7.78^{\mathrm{abc}}$ & $67.00 \pm 4.24^{\text {abcdef }}$ & $120.50 \pm 7.78 \mathrm{ab}$ \\
\hline 12 & $47.50 \pm 4.50^{\mathrm{abc}}$ & $64.00 \pm 11.37$ abcdef & $101.00 \pm 16.97 \mathrm{ab}$ \\
\hline 21 & $46.50 \pm 3.54^{\mathrm{abc}}$ & $64.00 \pm 8.49 \mathrm{abcdef}$ & $108.50 \pm 24.75^{\mathrm{ab}}$ \\
\hline 23 & $51.00 \pm 2.83^{\mathrm{abc}}$ & $64.00 \pm 9.90^{\text {abcdef }}$ & $109.00 \pm 25.46^{\mathrm{ab}}$ \\
\hline 24 & $46.00 \pm 0.00^{\mathrm{abc}}$ & $64.00 \pm 9.90^{\text {abcdef }}$ & $102.00 \pm 25.46^{\mathrm{ab}}$ \\
\hline 35 & $51.50 \pm 2.12^{\mathrm{abc}}$ & $64.50 \pm 7.78^{\text {abcdef }}$ & $100.50 \pm 26.16^{\mathrm{ab}}$ \\
\hline 43 & $64.00 \pm 0.00^{\mathrm{abc}}$ & $86.00 \pm 0.00^{\text {ef }}$ & $122.00 \pm 0.00^{\mathrm{ab}}$ \\
\hline 44 & $62.00 \pm 5.66^{\mathrm{abc}}$ & $105.00 \pm 0.00^{\text {abcdef }}$ & $131.00 \pm 36.77^{\mathrm{ab}}$ \\
\hline 45 & $44.00 \pm 0.00^{\mathrm{abc}}$ & $63.00 \pm 0.00^{\mathrm{abcdef}}$ & $145.00 \pm 0.00^{\mathrm{ab}}$ \\
\hline 51 & $49.00 \pm 4.24^{\mathrm{abc}}$ & $67.00 \pm 5.66^{\text {abcdef }}$ & $107.00 \pm 26.87^{\mathrm{ab}}$ \\
\hline 62 & $45.00 \pm 1.41^{\mathrm{abc}}$ & $64.50 \pm 9.19^{a b c d e f}$ & $126.00 \pm 0.00^{\mathrm{ab}}$ \\
\hline 70 & $52.00 \pm 1.41^{\mathrm{abc}}$ & $68.50 \pm 3.54^{\text {abcdef }}$ & $112.50 \pm 19.09 \mathrm{ab}$ \\
\hline 71 & $45.50 \pm 4.50^{\mathrm{abc}}$ & $65.00 \pm 4.24^{\text {abcdef }}$ & $111.50 \pm 17.68^{\mathrm{ab}}$ \\
\hline 72 & $50.00 \pm 7.07 \mathrm{abc}$ & $68.00 \pm 2.83^{\text {abcdef }}$ & $100.00 \pm 26.87 \mathrm{ab}$ \\
\hline 73 & $41.00 \pm 0.00^{\mathrm{ab}}$ & $56.50 \pm 0.71^{\text {abcd }}$ & $113.50 \pm 0.71^{\mathrm{ab}}$ \\
\hline 75 & $52.00 \pm 2.83^{\mathrm{abc}}$ & $75.00 \pm 0.00$ cdef & $104.50 \pm 16.26^{\mathrm{ab}}$ \\
\hline 76 & $47.50 \pm 0.71^{\mathrm{abc}}$ & $61.00 \pm 4.24^{\text {abcdef }}$ & $114.50 \pm 3.54^{\mathrm{ab}}$ \\
\hline 80 & $44.00 \pm 0.00^{\mathrm{abc}}$ & $69.00 \pm 0.00^{\text {bcdef }}$ & $124.00 \pm 0.00^{\mathrm{ab}}$ \\
\hline 92 & $75.00 \pm 7.07^{\mathrm{abc}}$ & $98.00 \pm 0.00^{\text {abcdef }}$ & $163.00 \pm 0.00^{b}$ \\
\hline 95 & $34.50 \pm 19.09 \mathrm{ab}$ & $51.00 \pm 7.07 \mathrm{abcd}$ & $111.00 \pm 1.41^{\mathrm{ab}}$ \\
\hline 96 & $36.50 \pm 12.02^{\mathrm{ab}}$ & $60.50 \pm 10.61^{\text {abcdef }}$ & $106.00 \pm 16.97 \mathrm{ab}$ \\
\hline 98 & $47.50 \pm 12.02^{\mathrm{abc}}$ & $78.00 \pm 0.00^{\text {def }}$ & $121.00 \pm 0.00^{\mathrm{ab}}$ \\
\hline 99 & $45.00 \pm 0.00^{\mathrm{abc}}$ & $63.00 \pm 0.00^{\text {abcdef }}$ & $111.00 \pm 0.00^{\mathrm{ab}}$ \\
\hline 101 & $42.50 \pm 0.71^{\mathrm{abc}}$ & $55.50 \pm 3.54^{\text {abcd }}$ & $110.00 \pm 1.41^{\mathrm{ab}}$ \\
\hline 104 & $43.50 \pm 7.78^{\mathrm{abc}}$ & $54.00 \pm 4.24^{\mathrm{abcd}}$ & $114.50 \pm 20.51^{\mathrm{ab}}$ \\
\hline 107 & $45.00 \pm 0.00^{\mathrm{abc}}$ & $65.00 \pm 0.00^{\text {abcdef }}$ & $111.00 \pm 0.00^{\mathrm{ab}}$ \\
\hline 109 & $48.00 \pm 0.00 \mathrm{abc}$ & $88.00 \pm 0.00^{\mathrm{f}}$ & $101.50 \pm 14.85^{\mathrm{ab}}$ \\
\hline 110 & $49.50 \pm 2.12^{\mathrm{abc}}$ & $64.50 \pm 4.50^{\text {abcdef }}$ & $118.00 \pm 11.31^{\mathrm{ab}}$ \\
\hline 111 & $52.50 \pm 2.12^{\mathrm{abc}}$ & $63.00 \pm 1.41^{\text {abcdef }}$ & $116.50 \pm 9.19^{\mathrm{ab}}$ \\
\hline 112 & $55.50 \pm 7.78 \mathrm{abc}$ & $70.50 \pm 10.61^{\text {bcdef }}$ & $120.00 \pm 14.14^{\mathrm{ab}}$ \\
\hline 120 & $51.50 \pm 0.71 \mathrm{abc}$ & $70.00 \pm 0.00$ bcdef & $116.00 \pm 22.63^{a b}$ \\
\hline 121 & $31.50 \pm 23.33^{\mathrm{ab}}$ & $57.00 \pm 5.66^{\mathrm{abcd}}$ & $92.00 \pm 0.00^{\mathrm{a}}$ \\
\hline 123 & $41.50 \pm 14.85^{\mathrm{ab}}$ & $53.00 \pm 15.56^{\text {abcd }}$ & $114.00 \pm 25.46^{\mathrm{ab}}$ \\
\hline 124 & $47.50 \pm 3.54^{\mathrm{abc}}$ & $60.00 \pm 2.83^{\text {abcde }}$ & $115.00 \pm 11.31^{\mathrm{ab}}$ \\
\hline 125 & $49.5 \pm 0.71^{\mathrm{abc}}$ & $58.00 \pm 0.00^{\text {abcd }}$ & $105.50 \pm 7.78^{\mathrm{ab}}$ \\
\hline 132 & $35.00 \pm 0.00^{\mathrm{ab}}$ & $47.00 \pm 1.41^{\mathrm{ab}}$ & $97.00 \pm 15.56^{\mathrm{ab}}$ \\
\hline 134 & $35.00 \pm 2.83^{\mathrm{ab}}$ & $48.50 \pm 0.71^{\mathrm{abc}}$ & $97.50 \pm 16.26^{\mathrm{ab}}$ \\
\hline 136 & $27.50 \pm 19.09 a$ & $41.00 \pm 16.97 a$ & $103.00 \pm 22.62^{\mathrm{ab}}$ \\
\hline 143 & $41.50 \pm 3.54^{\mathrm{ab}}$ & $60.00 \pm 4.24^{\text {abcde }}$ & $98.50 \pm 17.68^{\mathrm{ab}}$ \\
\hline \multicolumn{4}{|l|}{ Year } \\
\hline 2008 & $45.44 \pm 11.67^{\mathrm{a}}$ & $66.21 \pm 13.60^{a}$ & $115.68 \pm 15.42^{\mathrm{a}}$ \\
\hline 2009 & $48.17 \pm 8.78^{a}$ & $63.83 \pm 13.06^{\mathrm{a}}$ & $108.27 \pm 19.29^{b}$ \\
\hline
\end{tabular}

SD-standard deviation

Analysis of variance (ANOVA) and the Tukey HSD test were used for statistical evaluation (software -

Statistica 7.0 CZ).

Different letters in the same row are statistically significant at $\mathrm{p}>0.05$.

Table 2. Phenological evaluation of amaranths 


\begin{tabular}{|c|c|c|c|c|}
\hline & Inflorescence length (cm) & Plant height (cm) & WTS (g) & Colour of seed \\
\hline Genotype & Mean \pm SD & Mean \pm SD & Mean $\pm S D$ & \\
\hline 6 & $54.00 \pm 1.41^{\mathrm{de}}$ & $137.50 \pm 3.54^{\mathrm{bcd}}$ & $0.75 \pm 0.01^{\text {cdefghijk }}$ & pale \\
\hline 11 & $56.50 \pm 0.71^{\text {de }}$ & $137.50 \pm 45.96^{\mathrm{bcd}}$ & $0.69 \pm 0.08^{\text {bcdefghij }}$ & pale \\
\hline 12 & $29.50 \pm 0.71^{\text {bc }}$ & $117.50 \pm 3.54^{\mathrm{abcd}}$ & $0.68 \pm 0.04^{\text {bcdefghij }}$ & pale \\
\hline 21 & $34.00 \pm 1.41^{\mathrm{bcd}}$ & $90.00 \pm 7.07 \mathrm{abc}$ & $0.58 \pm 0.03^{\text {abcdefg }}$ & pink \\
\hline 23 & $44.50 \pm 0.71^{\text {cde }}$ & $127.50 \pm 3.54^{\text {bcd }}$ & $0.76 \pm 0.08^{\text {cdefghijk }}$ & black \\
\hline 24 & $66.00 \pm 1.41^{\mathrm{e}}$ & $152.50 \pm 3.54^{\mathrm{cd}}$ & $0.75 \pm 0.07$ cdefghijk & black \\
\hline 35 & $30.50 \pm 0.71^{\text {bc }}$ & $167.50 \pm 3.54^{\mathrm{d}}$ & $0.90 \pm 0.00^{\mathrm{ijk}}$ & pale \\
\hline 43 & $36.00 \pm 0.00^{\mathrm{bcd}}$ & $150.00 \pm 0.00^{\mathrm{cd}}$ & $0.74 \pm 0.04^{\text {cdefghijk }}$ & pale \\
\hline 44 & $24.50 \pm 0.71^{\mathrm{a}}$ & $147.50 \pm 3.54^{\mathrm{cd}}$ & $0.74 \pm 0.00^{\text {cdefghijk }}$ & pale \\
\hline 45 & $29.00 \pm 0.00^{\mathrm{bc}}$ & $100.00 \pm 0.00^{\mathrm{abc}}$ & $0.88 \pm 0.00^{\text {hijk }}$ & pale \\
\hline 51 & $29.00 \pm 0.00^{\mathrm{bc}}$ & $142.50 \pm 3.54^{\mathrm{bcd}}$ & $0.85 \pm 0.00^{\text {hijk }}$ & pale \\
\hline 62 & $37.50 \pm 0.71^{\mathrm{bcd}}$ & $137.50 \pm 3.54^{\mathrm{bcd}}$ & $0.66 \pm 0.06^{\text {abcdefghi }}$ & black \\
\hline 70 & $45.50 \pm 0.71^{\text {cde }}$ & $102.50 \pm 3.54^{\mathrm{abcd}}$ & $0.78 \pm 0.05^{\text {efghijk }}$ & pale \\
\hline 71 & $52.50 \pm 0.71^{\text {cde }}$ & $132.50 \pm 3.54^{\mathrm{bcd}}$ & $0.86 \pm 0.15^{\text {hijk }}$ & pale \\
\hline 72 & $46.50 \pm 0.71^{\text {cde }}$ & $122.50 \pm 3.54^{\mathrm{bcd}}$ & $0.93 \pm 0.10^{\mathrm{jk}}$ & pale \\
\hline 73 & $41.50 \pm 0.71$ cde & $130.00 \pm 8.49 \mathrm{bcd}$ & $0.71 \pm 0.01^{\text {cdefghijk }}$ & pale \\
\hline 75 & $60.00 \pm 0.00 \mathrm{e}$ & $132.50 \pm 3.54^{\mathrm{bcd}}$ & $0.91 \pm 0.10^{\mathrm{ijk}}$ & pale \\
\hline 76 & $36.50 \pm 3.54^{\mathrm{bcd}}$ & $109.00 \pm 4.24^{\text {abcd }}$ & $0.84 \pm 0.08$ ghijk & pale \\
\hline 80 & $47.00 \pm 0.00^{\text {cde }}$ & $125.00 \pm 0.00^{\text {bcd }}$ & $0.50 \pm 0.00^{\text {abcd }}$ & black \\
\hline 92 & $51.00 \pm 1.41^{\mathrm{de}}$ & $142.50 \pm 3.54^{\mathrm{bcd}}$ & $0.84 \pm 0.00$ ghijk & pale \\
\hline 95 & $35.50 \pm 0.71^{\text {bcd }}$ & $92.50 \pm 3.54^{\mathrm{abc}}$ & $0.63 \pm 0.11^{\text {abcdefgh }}$ & black \\
\hline 96 & $34.00 \pm 1.41^{\text {bcd }}$ & $92.60 \pm 3.54^{\mathrm{abc}}$ & $0.40 \pm 0.04^{\mathrm{a}}$ & black \\
\hline 98 & $43.50 \pm 0.71^{\text {cde }}$ & $152.50 \pm 3.54^{\mathrm{cd}}$ & $0.96 \pm 0.00^{\mathrm{k}}$ & pale \\
\hline 99 & $44.00 \pm 0.00^{\text {cde }}$ & $110.00 \pm 0.00^{\mathrm{abcd}}$ & $0.70 \pm 0.00^{\text {bcdefghijk }}$ & black \\
\hline 101 & $38.00 \pm 0.00^{\mathrm{bcd}}$ & $127.50 \pm 36.06^{\mathrm{bcd}}$ & $0.5 \pm 0.02^{\mathrm{abc}}$ & pink \\
\hline 104 & $42.50 \pm 0.71^{\text {cde }}$ & $92.50 \pm 3.54^{\mathrm{abc}}$ & $0.63 \pm 0.04^{\text {abcdefgh }}$ & black \\
\hline 107 & $22.00 \pm 0.00^{\mathrm{a}}$ & $53.00 \pm 0.00^{\mathrm{a}}$ & $0.52 \pm 0.00^{\text {abcde }}$ & black \\
\hline 109 & $34.50 \pm 0.71^{\mathrm{bcd}}$ & $77.50 \pm 3.54^{\mathrm{ab}}$ & $0.44 \pm 0.04^{\mathrm{ab}}$ & black \\
\hline 110 & $49.50 \pm 0.71^{\text {cde }}$ & $155.00 \pm 7.07 \mathrm{~cd}$ & $0.70 \pm 0.00^{\text {bcdefghijk }}$ & black \\
\hline 111 & $52.00 \pm 1.41^{\mathrm{de}}$ & $137.50 \pm 3.54^{\mathrm{bcd}}$ & $0.52 \pm 0.11^{\text {abcde }}$ & black \\
\hline 112 & $53.00 \pm 2.83^{\mathrm{de}}$ & $127.50 \pm 3.54^{\mathrm{bcd}}$ & $0.84 \pm 0.01$ ghijk & pale \\
\hline 120 & $51.50 \pm 2.12^{\mathrm{de}}$ & $95.00 \pm 42.43 \mathrm{abc}$ & $0.73 \pm 0.03$ cdefghijk & pale \\
\hline 121 & $36.50 \pm 2.12^{\mathrm{bcd}}$ & $115.00 \pm 21.21^{\mathrm{abcd}}$ & $0.54 \pm 0.17$ abcdef & pale \\
\hline 123 & $47.00 \pm 0.00^{\text {cde }}$ & $102.50 \pm 3.54^{\mathrm{abcd}}$ & $0.80 \pm 0.00^{\text {fghijk }}$ & pale \\
\hline 124 & $54.50 \pm 0.71^{\mathrm{de}}$ & $137.50 \pm 3.54^{\mathrm{bcd}}$ & $0.82 \pm 0.06 \mathrm{ghijk}$ & pale \\
\hline 125 & $51.50 \pm 0.71 \mathrm{de}$ & $127.50 \pm 3.54^{\mathrm{bcd}}$ & $0.75 \pm 0.14^{\text {cdefghijk }}$ & pale \\
\hline 132 & $46.50 \pm 4.50^{\text {cde }}$ & $114.50 \pm 23.33^{\mathrm{abcd}}$ & $0.77 \pm 0.01^{\text {efghijk }}$ & pale \\
\hline 134 & $44.50 \pm 3.54^{\text {cde }}$ & $119.50 \pm 17.68^{\text {bcd }}$ & $0.81 \pm 0.08^{\text {fghijk }}$ & pale \\
\hline 136 & $45.50 \pm 3.54^{\text {cde }}$ & $92.50 \pm 38.89 \mathrm{abc}$ & $0.77 \pm 0.01^{\text {defghijk }}$ & pale \\
\hline 143 & $39.50 \pm 2.12^{\mathrm{bcd}}$ & $107.50 \pm 38.89 \mathrm{abcd}$ & $0.79 \pm 0.02^{\text {efghijk }}$ & pale \\
\hline \multicolumn{5}{|l|}{ Year } \\
\hline 2008 & $42.71 \pm 9.90^{\mathrm{a}}$ & $122.85 \pm 26.21 \mathrm{a}$ & $0.72 \pm 0.15^{\mathrm{a}}$ & \\
\hline 2009 & $43.22 \pm 9.87^{a}$ & $119.02 \pm 26.36^{\mathrm{a}}$ & $0.73 \pm 0.14^{\mathrm{a}}$ & \\
\hline
\end{tabular}

Different letters in the same row are statistically significant at $\mathrm{p}>0.05$.

SD-standard deviation

Analysis of variance (ANOVA) and the Tukey HSD test were used for statistical evaluation (software -

Statistica 7.0 CZ).

Table 3. Morphological evaluation of amaranth 
important for mechanized harvest by combine harvester. Lower plants with mean inflorescence are better for grain production and mechanized harvest. From our collection it is for example accession ' 120 ' with $95.00 \pm 42.43 \mathrm{~cm}$ height and $51.50 \pm 2.12 \mathrm{~cm}$ length of inflorescence. Taller genotypes are useful to develop varieties for feed utilization (Wu eta l., 2000). On the other hand, plant height could be influenced by increasing of number of plant per $\mathrm{m}^{2}$ (Jarošová et al., 1997). The value of weight of thousand seeds (WTS) is shown in table 3. In the relation with seed colour is clear, that the biggest WTS was observed in pale seeded samples. The seed size of the genera ranges from 0.37 to $1.21 \mathrm{~g}$ per 1000 seed weight according to Espitia-Rangel (1994). He noted that the low value corresponding to wild and weedy species and the high values to cultivated grain species. In our experiments the WTS ranged from 0.39 to $0.96 \mathrm{~g}$.

\subsection{Protein content and content of protein fractions}

The results of the protein content analysis showed that the highest protein content $(17.32 \pm$ $0.82 \%)$ had $A$. cruentusaccessions followed by $A$. caudatus $(17.24 \pm 0.65 \%)$ and $A$. hypochondriacus $(16.89 \pm 0.80 \%)$. It corresponds with other published data. Segura-Nieto et al. (1994) published, that the range of protein content is following: A. cruentus $13.2-18.2 \%, A$. hypochondriacus $17.9 \%$ and $A$. caudatus $17.6-18.4 \%$. The range of the total protein content into our collection $(12.43-17.33 \%)$ was similar to the results of other authors investigating various amaranth genotypes (Barba de la Rosa et al., 2009). The amaranth albumins, globulins and prolamins formed $9.2-14.65 \%, 9.78-13.81 \%$ and $1.76-3.3 \%$ of total seed protein, respectively (Table 4). The glutelins with the residual nitrogen were the most abundant. It was in accordance with the results of Bressani \& Garcia-Vela (1990) and Bejosano \& Corke (1999a). The very low content of prolamins $(1.76-3.3 \%)$ confirmed the results of several authors (Gorinstein et al., 1991a; Bejosano \& Corke, 1999a; Petr et al., 2003). However, another group of authors reported several times more prolamins (Correa et al., 1986; Zheleznov et al., 1997; Vasco-Mendez \& Paredes-Lopez, 1995). The differences between the results of these two groups of authors might be due to the different extraction methods (Fidantsi \& Doxastakis, 2001). Significant differences between black, pale and pink coloured seeds in the content of albumins were detected. Content of albumins of the black seeded group $(9.64 \pm 0.40 \%)$ was significantly lower ( $p$-value $\left.4.10^{-3}\right)$ than of the pale seeded group $(13.21 \pm 1.45 \%)$ and also lower than of the pink seeded group (11.39 \pm 0.00 ; p-value 2.10-2). Bresani \& Garcia-Vela (1990) did not observed any differences in the protein fractions distribution among species or cultivars of the same species, independent of the fractionation sequence used. However, our results showed that the black seeded varieties had the lowest albumin content. No significant differences in other protein fractions were detected.

\begin{tabular}{|l|c|c|c|c|}
\hline & \multicolumn{4}{|c|}{ Seed colour } \\
\cline { 2 - 5 } & black & pale & pink & range \\
\hline WTS (g) & $0.60 \pm 0.12$ & $0.79 \pm 0.09$ & $0.54 \pm 0.04$ & $0.39-0.96$ \\
\hline Protein content in \% & $15.69 \pm 0.60$ & $16.69 \pm 0.78$ & $16.04 \pm 0.00$ & $12.43-17.33$ \\
\hline Albumins & $9.64 \pm 0.40$ & $13.21 \pm 1.45$ & $11.39 \pm 0.00$ & $9.2-14.65$ \\
\hline Globulins & $10.92 \pm 0.781$ & $11.76 \pm 1.72$ & $10.75 \pm 0.00$ & $9.78-13.81$ \\
\hline Prolamins & $2.37 \pm 0.82$ & $2.68 \pm 0.44$ & $2.00 \pm 0.00$ & $1.76-3.3$ \\
\hline Glutelins + residual nitrogen & $77.07 \pm 0.33$ & $72.35 \pm 2.67$ & $75.86 \pm 0.00$ & $69.13-77.44$ \\
\hline
\end{tabular}

Table 4 . Total seed protein content and protein fraction content (in $\%$ of DW) of investigated accessions with respect the seed colour. 


\subsection{Methodical approach to protein extraction}

According to our results, the chip capillary electrophoresis could replace the standard SDSPAGE procedure, because it produced comparable results and what is more it could be performed routinely also in small laboratories thanks to its rapid performance. On the other hand, the chip capillary electrophoresis showed wider range of proteins spectra (up to $260 \mathrm{kDa}$ ).

The test of different concentrations was used for selection of the best extraction approach for chip and SDS-PAGE electrophoresis. By the chip capillary electrophoresis, the bulked samples of 100 seeds in $400 \mu$ l of extraction buffer were also tested. The chip capillary electrophoresis showed the high sensitivity and therefore the high concentration of the protein in the main bands resulted in their illegility. The protocol of chip electrophoresis does not provide many possibilities to chase the loaded amount of the sample. The satisfactory results of the chip electrophoresis brought the use of the single seeds.

For the SDS PAGE there were used single seed samples, bulked samples of 10 seeds extracted in 50 and $100 \mu \mathrm{l}$ and bulked samples of 100 seeds extracted in 200 and $400 \mu l$ of extraction solution were used. The protein patterns of the samples extracted from the single seeds did not show the intensity required for the analysis of all the bands in the spectra (Figure 1). On the other hand, samples obtained by extraction of 10 seeds in $50 \mu l$ and 100 seeds extracted in 200 $\mu \mathrm{l}$ of extraction solution did not show clearly separated bands, what resulted in their illegility. In comparison with the spectra of the less concentrated samples (single seeds, 10 seeds in 100 $\mu \mathrm{l}$ of extraction solution), the main bands of the more concentrated samples were thick and joined together. The bands, which were in the less concentrated samples less intensive, were expressed so intensively that formed dark background what resulted in the impossibility of identification of the individual bands in the protein spectra. The protein spectra of the samples obtained by the extraction of 100 seeds in $400 \mu \mathrm{l}$ were also over expressed, but the less intensive bands did not form the background, so the mayor bands were more easily identified, but several mayor bands joined together.

As the best approach for the total seed storage protein extraction for classical SDS-PAGE we selected bulked samples of 10 seed extracted in $100 \mu$ l of extraction solution. The bulked samples of 10 seeds extracted in $100 \mu \mathrm{l}$ to be the most suitable tools, because of their clear expression of protein patterns and moreover they can be used when samples with higher number of seeds are not available. This selected approach differed from methodology selected by Drzewiecki (2001) who used $50 \mu \mathrm{l}$ or by Gorinstein et al. (2005) who used $62.5 \mu \mathrm{l}$ of extraction solution for 10 seeds bulked samples. The need for using more extraction solution in our study might be to consequence of higher protein extraction as a result of the proper seed crushing performed in our study which was not mentioned in the methodology description of other authors (Drzewiecki, 2001; Gorinstein et al., 2005).

When using total seed storage protein spectra for accessions identification by chip electrophoresis the single seed samples with several repetitions showed up as the best approach. These results were with accordance with Bradova \& Matejova (2008) that compared whole seed storage proteins of wheat.

\subsection{Polymorphism of the glutelins}

The electrophoresis of the glutelin fraction is widely used for crop varieties identification. There were published several articles about wheat (Matejova\&Bradova, 2008; Dutta et al., 
2011), rice (Gorinstein et al., 2003), barley (Smith \& Simpson, 1983), lupine (Vaz et al., 2004) etc. varieties identification based on glutelin patterns. Similarly amaranth glutelins showed polymorphism not only in position of bands but also in their intensity.

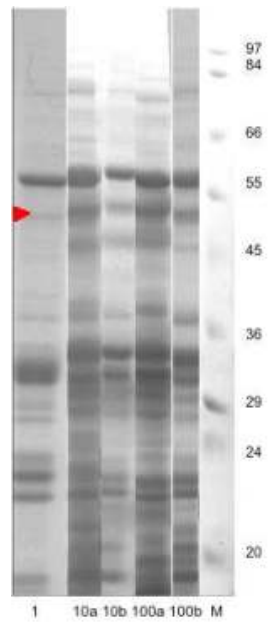

1 - a single seed extracted in $18 \mu \mathrm{l}$,

$10 \mathrm{a}$ - bulk of 10 seeds extracted in $50 \mu \mathrm{l}$,

$10 \mathrm{~b}$ - bulk of 10 seeds extracted in $100 \mu \mathrm{l}$,

$100 \mathrm{~b}$ - bulk of 100 seeds extracted in $400 \mu \mathrm{l}$ of the extraction solution.

$\mathrm{M}$ - wide range protein marker (bands in $\mathrm{kDa}$ ).

Fig. 1. SDS - PAGE spectra of total seed storage proteins of sample obtained by different extraction approaches.

In the cluster dendrogram (Figure2), there were clearly separated the grain and the wild monoecious and the wild dioecious accessions. All investigated amaranth species had in common three major bands of the MW $21-23 \mathrm{kDa}$, but remarkable differences in the rest of the spectra were the reason for the segregation into three main clusters. The glutelin spectra of the grain amaranth varieties were very similar to the total seed storage protein patterns, but the main polymorphic bands were better distinguished because of the washing off the first three fractions during fraction separation procedure which probably formed the "background" of the spectra. The principal polymorphism was detected in following band positions 38, 39, 54, 58, 60, 64 and $65 \mathrm{kDa}$ with three intensity levels (1-3). The amaranth glutelins showed up as the most abundant protein fraction by SDS-PAGE analysis also in the study of Bejosano\&Corke (1999). The division of the grain amaranth glutelins into three major groups reported also Gorinstein et al. (2004) and Barba de la Rosa et al. (2009).

Figure 2 indicated three well defined clusters: grain species, monoecious wild species and dioecious wild species. The grain species A. cruentus, A. hypochondriacus, A. caudatus closely matched together with one sample $A$. mantegazzianus. There were clearly segregated clusters with the wild monoecious species (A.wrightii, A. delfexus and A. retroflexus) and the wild dioecous species (A. australis, A. cannabinus and $A$. tuberculatus). 
A. caudatus group presentedwas two accessions ' 21 ' and ' 101 ' characterized by the dark band $60 \mathrm{kDa}$ and the light band $39 \mathrm{kDa}$ in their glutelin spectra. The A. cruentus cluster was clearly separated in the dendrogram of hierarchical distancing by the presence of the dark band of $58 \mathrm{kDa}$ and of the light band in the position of $39 \mathrm{kDa}$. A. hypochondriacus accessions were characterized by the lack of any band in the position $58 \mathrm{kDa}$ and by the presence of the dark band $54 \mathrm{kDa}$ and the light band $38 \mathrm{kDa}$. The typical band (in the position $54 \mathrm{kDa}$ ) used for A. hypochondriacus recognition was qualified as characteristic for A. hypochondriacus by several authors (Drzewiecki, 2001; Marcone, 2002; Gorinstein et al., 2005), but its position was determined differently: as $55 \mathrm{kDa}$ (Marcone, 2002) or $52 \mathrm{kDa}$ (Drzewiecki, 2001) or in the case of protein fractions as $55 \mathrm{kDa}$, too (Thanapornpoonpong et al., 2008). The characteristic presence of the band $58 \mathrm{kDa}$ in A. cruentus spectra and of the band $54 \mathrm{kDa}$ in A. hypochondriacus spectra was confirmed by the results of Thanapornpoonpong et al. (2008).

Some of the accessions possessed extra light band of $65 \mathrm{kDa}$ and were aggregated close to the A. hypochondriacus cluster. Their similarity to the other A. hypochondriacus varieties was expressed by very high correlation 0.987 .

The dark band of $54 \mathrm{kDa}$, the dark band of $64 \mathrm{kDa}$ and the light band in the position $65 \mathrm{kDa}$ showed up in the glutelin spectra of the accession '134'. The accession ' 80 ' had the same glutelin spectra, but its band of $54 \mathrm{kDa}$ was of medium intensity. These two varieties might be the hybrids of $A$. hypochondriacus and other unknown species which could have dark band of $64 \mathrm{kDa}$ and light band of $39 \mathrm{kDa}$ or they might be A. hypochondriacus varieties with some special properties that were not considered in our study. The accessions '132' with the dark band of $60 \mathrm{kDa}$ typical for A. caudatus accessions was also present in the spectra and therefore the correlation between these accessions and the A. caudatus accessions was as high as 0.911 . These accessions also showed the light band of $38 \mathrm{kDa}$ and the medium intensity band of $54 \mathrm{kDa}$ (typical marker for A. hypochondriacus spectra).

The dioecious wild species A. australis, A. cannabinus and A. tuberculatus formed a totally distinct cluster. They possessed several major dark bands of lower molecular weight 32 - 50 $\mathrm{kDa}$. From this group, A. cannabinus and A. australis were the most similar, their correlation was 0.675 . The monoecious wild species (A. wrightii, A. deflexus and A. retroflexus) and the dioecious wild species had in common one light band in the position of $65 \mathrm{kDa}$. The major dark bands of the monoecious wild species were of MW 29 - $66 \mathrm{kDa}$. The spectra of the monoecious wild species had some similarities with the spectra of the grain species. The grain species spectra were characterized by the two bands of MW 31 and $33 \mathrm{kDa}$ while in the spectra of A. retroflexus these bands were just "shifted up" to MW 32 and $34 \mathrm{kDa}$. Protein fractions spectra of the wild species had not been published yet by other researchers. The results indicated the high correlation of the spectra of A. retroflexus and A. wrightii what confirmed the similarity observed by the first morphological descriptions made by Watson (1877).

Accessions possessing several bands of different intensities in the polymorphic area were qualified as the hybrid accessions. The accession '99' had in its spectra several bands in the polymorphic area: the dark band of $54 \mathrm{kDa}$, light band of $58 \mathrm{kDa}$, medium intensity band in the position of $60 \mathrm{kDa}$ and the light band of $65 \mathrm{kDa}$. Its similarity with A. hypochondriacus was expressed as correlation 0.901 and to the accession ' 95 '. The accession ' 95 ' differed from the accession '99' just in the intensity of the bands of $58 \mathrm{kDa}$ and $60 \mathrm{kDa}$ (correlation 0.971). Varieties ' 62 ' and ' 110 ' were designated as hybrid varieties. They had the both bands of 54 $\mathrm{kDa}$ (marker for A. cruentus) and $58 \mathrm{kDa}$ (marker for A. hypochondriacus) of medium 
intensity. Moreover, they possessed the light band of $39 \mathrm{kDa}$. The presence of the light band $39 \mathrm{kDa}$ (typical marker for $A$. cruentus) was the reason for their higher correlation with $A$. cruentus group (0.920) than with A. hypochondriacus group (0.892). The variety '111' was exceptional. Moreover, it had higher correlation with $A$. hypochondriacus varieties $(0.960)$.
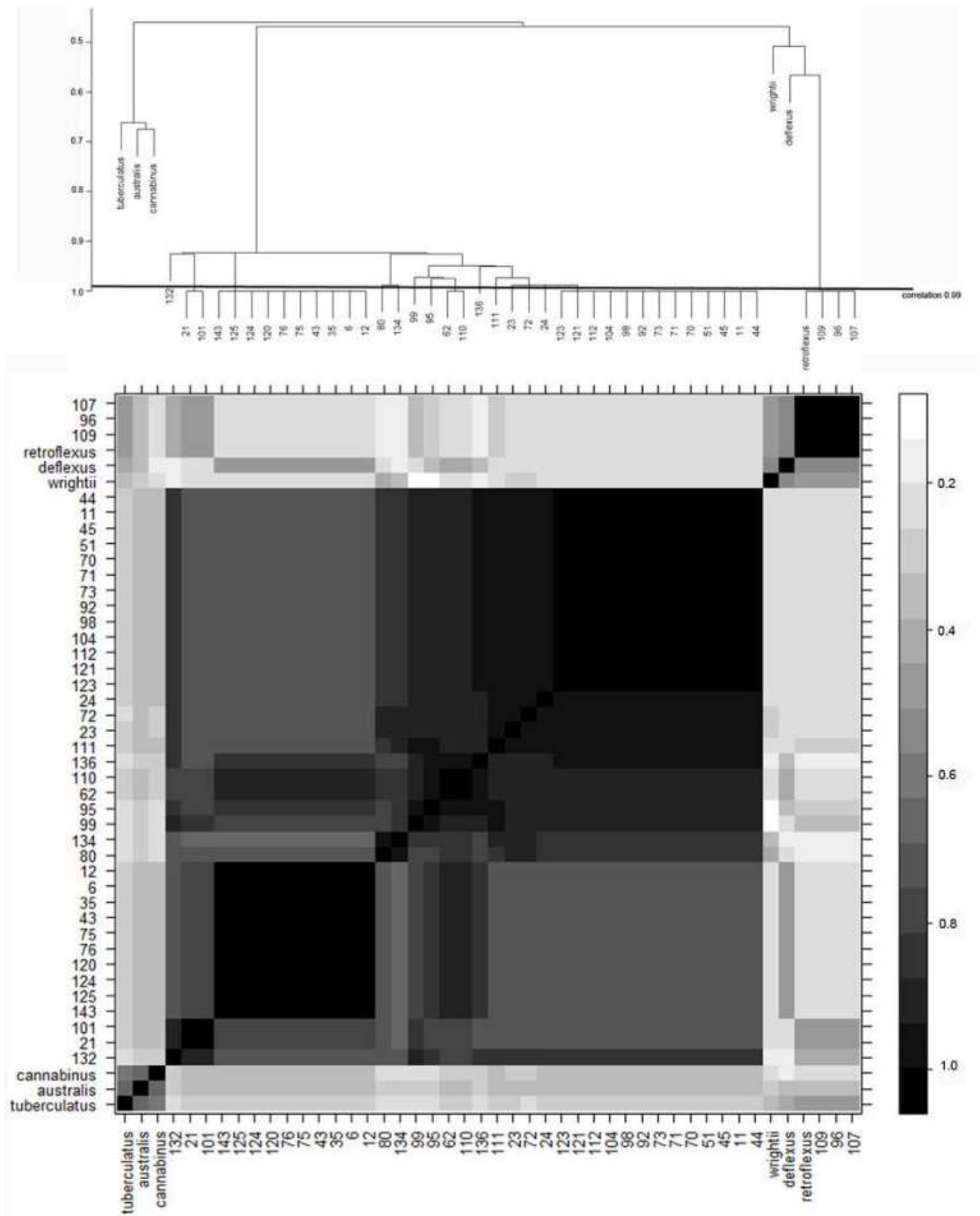

Fig. 2. Relations among amaranth samples expressed by Pearson correlation in dendrogram 


\section{Conclusion}

Amaranth is mostly named as a crop of the future. Due to very good contents of protein, oil and many components with positive effects to humans, it is one of the promising crops. In the Czech Republic, there was interest of amaranth growing in the fields and the consumption of amaranth products is increasing as well. Most of grain raw material is imported to the Czech Republic from other countries, but there is increasing demand of Czech amaranth production. For amaranth cultivation it is necessary to know, what species could be grown. Because amaranth is not native in Europe, we have to receive seeds from other sides. In Czech legislation act about invasive weeds exists. Several amaranth species are included in this Act. In order to avoid cultivation of weedy amaranths, it is necessary to know the characteristics of the cultivated species and do not confuse them. Due to vegetable and weedy amaranth have black seed colour, it is impossible to use this trait as a marker. Amaranth glutelins were the best tool for the amaranth species identification, because they showed high polymorphism not only in position of bands but also in their intensity. The method used here was based on the data concerning the relative intensity and the position of the bands in the glutelin spectra obtained by the chip capillary electrophoresis what resulted in the exact similarity calculation of the protein fraction spectra and thus in the segregation of the cultivated grain species, the monoecious wild species and the dioecious wild species into three separate clusters. Each of the grain amaranth species was characterized by one dark band in the polymorphic region (54 - $65 \mathrm{kDa}$ ), while the hybrids possessed more bands of different relative intensity. The study brought several new contributions to the amaranth genetic research and is a very useful tool for species identification before cultivation in the field conditions. Unfortunately, this method is not so sensitive for individual amaranth genotype identification. We work on it in our current tasks.

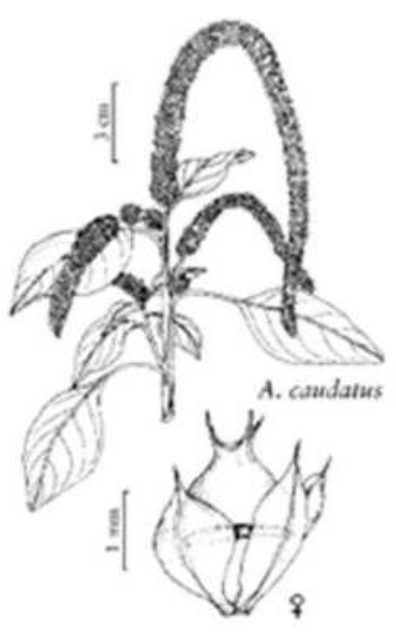

Fig. 3. A. caudatus (Standley, 1949)

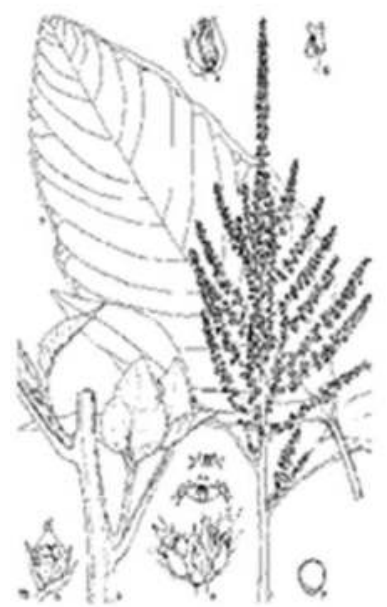

Fig. 4. A. hypochondriacus (NRC, 1984) 


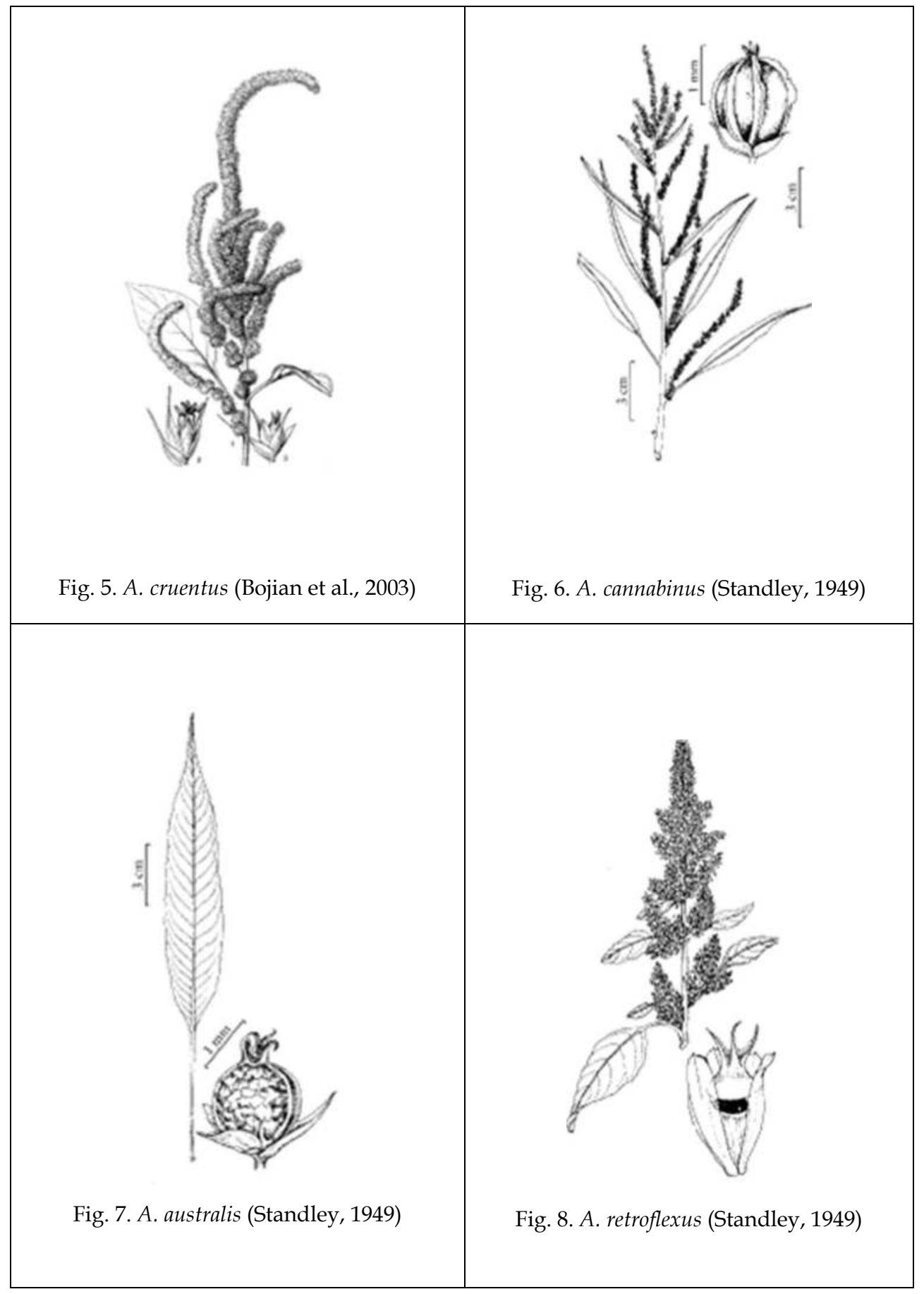




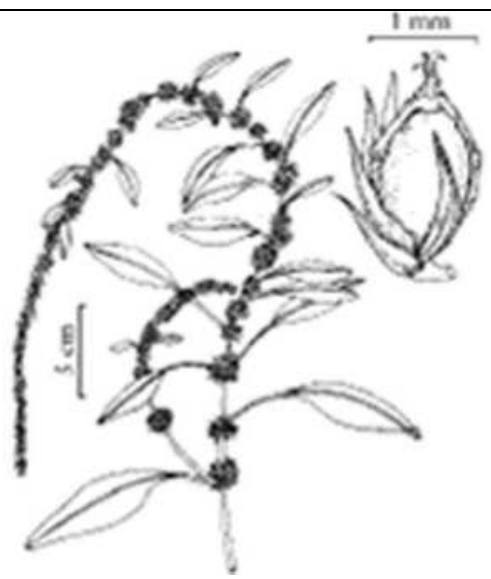

Fig. 9. A. tuberculatus (Standley, 1949)

\section{Acknowledgement}

This work was supported by the Czech Ministry of Agriculture QH92111.

\section{References}

Alvarez-Jubete, L.; Wijngaard, H.; Arendt, E.K. \& Gallagher, E. (2010). Polyphenol composition and in vitro antioxidant activity of amaranth, quinoa, buckwheat and wheat as affected by sprouting and Baking. Food Chemistry 119, pp. 770-778, ISSN 0308-8146

Barba de la Rosa, A.P.; Fomsgaard, I. S.; Larsen, B.; Mortensen, A. G.; Olvera-Martınez, L.; Silva-Sanchez, C.; Mendoza-Herrera, A.; Gonzalez-Castaneda J. \& De LeonRodriguez A. (2009). Amaranth (Amaranthus hypochondriacus) as an alternative crop for sustainable food production: Phenolic acids and flavonoids with potentialimpact on its nutraceutical quality. Journal of Cereal Science 49, pp. 117-121, ISSN 0733-5210

Becker, R. (1994). Amaranth Oil: Composition, Processing, and Nutritional Qualities. In: Amaranth: Biology, Chemistry and Technology. Paredes-Lopez O. (Ed.) 133-141. CRC, ISBN 0-8493-5374-2, Boca Raton, USA

Bejosano, F. P. \& Corke, H. (1999). Properties of protein concentrates and hydrolysates from Amaranthus and buckwheat. Industrial Crops and Products, 10 (3), pp. 175-183, ISSN 09266690

Bojian, B.; Clemants, S. E. \& Borsch T. (2003). Amaranthaceae. Flora of China 9: 415429.Available on internet http://hua.huh.harvard.edu/china/mss/welcome.htm [accessed 15. August 2011]

Brenner, D. M.; Baltensperger, D. D.; Kulakow, P. A.; Lehmann, J. W.; Myers, R. L.; Slabbert, M. M. \& Sleugh, B. B. (2000). Genetic resources and breeding of Amaranthus. Plant Breeding Reviews 19, pp. 227-285. ISBN 0-471-38787-8, John Wiley \& sons Inc. 
Bressani, R. \& Garcia-Vela, L. A. (1990). Protein Fractions in Amaranth Grain and Their Chemical Characterization. Journal of Agricultural and Food Chemistry, 38 (5), pp. 1205-1209, ISSN 0021-8561

Bradova, J. \& Matejova, E. (2008).Comparison of the Results of SDS PAGE and Chip Electrophoresis of Wheat Storage Proteins. Chromatographia 67, pp. S83-S88, ISSN 0009-5893

Chan, K. F. \& Sun, M. (1997). Genetic diversity and relationships detected by isozyme and RAPD analysis of crop and wild species of Amaranthus. Theoretical and applied genetics. 95: 865-873. ISSN: 1432-2242

Correa, A. D.; Jokl, L. \& Carlsson, R. (1986). Amino-acid composition of some Amaranthus sp. grain proteins and of its fractions. Archivos Latinoamericanos de Nutricion 36 (3), pp. 466-476,ISSN 0004-0622

Costea, M.; Sanders, A. \& Waines, G.J. (2001). Preliminary results towards revisions of the Amaranthus hybridus species complex (Amaranthaceae). SIDA 19 (4), pp. 931 - 974, ISSN 0833-1475

Das, S. (2011). Systematics and taxonomic delimitation of vegetable, grain and weed amaranths: a morphological and biochemical approach. Genetic Resources and Crop Evolution, 58, pp. 1-15, ISSN 1573-5109

Dotlačil, L.; Stehno, Z.; Michalová, A. \& Faberová, I. (2001). Plant genetic resources and agribiodiversity in the Czech Republic. In: Agriculture and Biodiversity: Developing Indicators for Policy Analysis Proceedings from an OECD Expert Meeting Zurich, November 2001. 66-79, Switzerland

Drzewiecki J. (2001). Similarities and Differences between Amaranthus Species and Cultivars and Estimation of Outcrossing Rate on the Basis of Electrophoretic Separations of Urea-Soluble Seed Proteins. Euphytica, 119 (3), pp. 279-287, ISSN 1573-5060

Drzewiecki, J.; Delgado-Licon, E.; Haruenkit, R.; Pawelzik, E.; Martin-Belloso, O.; Park, Y. S.; Jung, S. T.; Trakhtenberg, S. \& Gorinstein, S. (2003). Identification and Differences of Total Proteins and Their Soluble Fractions in Some Pseudocereals Based on Electrophoretic Patterns. Journal of Agricultural and Food Chemistry 51 (26), pp. 77987804, ISSN 0021-8561

Dvoracek V. (2006). Optimalizace Osbornovy metody kvantifikace bílkovinných frakcí zrna pšenice ozimé (Triticum aestivum L.). 10p. ISBN 80-86555-81-X - Available on: http://www.vurv.cz/files/Publications/OptimalizaceOsborn.pdf [cited: 2.9.2011]

Dutta, T.; Kaur, H.; Singh, S.; Mishra, A.; Tripathi, J. K.; Singh, N.; Pareek, A. \& Singh, P. (2011). Developmental changes in storage proteins and peptidylprolylcistransisomerase activity in grains of different wheat cultivars. Food Chemistry. 12, pp. 450-457, ISSN 0308-8146

Dzunkova, M.; Janovska, D.; Hlasna-Cepkova, P.; Prohaskova, A. \& Kolar, M. (2011). Glutelin protein fraction as a tool for clear identification of Amaranth accessions. Journal of Cereal Science, 53, 2, pp. 198 - 205, ISSN 0733-5210

EC (2007). Genetic resources in agriculture. A summary of the projects co-financed under Council Regulation (EC) No 1467/94 Community programme 1994-99, ISBN: 92-79-03599-1, Rome, Italy

Espitia-Rangel, E. (1994). Breeding of Grain Amaranth. In: Amaranth: Biology, Chemistry and Technology. Paredes-Lopez O. (Ed.).23-38. CRC, ISBN 0-8493-5374-2, Boca Raton, USA 
Fidantsi, A. \& Doxastakis, G. (2001). Emulsifying and foaming properties of amaranth seed protein isolates. Colloids and surfaces B: Biointerfaces, 21, 1-3, pp. 119-124, ISSN 18734367

Girija, K.; Lakshman, K.; Chandrika, U.; Ghosh, S. S. \& Divya, T. (2011). Anti-diabetic and anti-cholesterolemic activity of methanol extracts of three species of Amaranthus. Asian Pacific Journal of Tropical Biomedicine, pp. 133-138, ISSN 2221-1691

Gorinstein, S.; Moshe R. \& Greene, L. J. (1991). Evaluation of four Amaranthus species through protein electrophoretic patterns and their amino acid composition.Journal of Agricultural and Food Chemistry, 39 (5), pp. 851-854, ISSN 0021-8561

Gorinstein, S.; Pawelzik, E.; Delgado-Licon, E.; Haruenkit, R.; Weisz, M. \& Traktenberg, S. (2002). Characterization of Pseudocereals and Cereals Proteins by Protein and Amino Acid Analyses. Journal of the Science of the Food and Agriculture 82 (8), pp. 886-891, ISSN 1097-0010

Gorinstein, S.; Yamamoto, K.; Kobayashi, S.; Taniguchi, H.; Pawelzik, E.; Delgado-Licon, E.; Shaoxian, Y.; Hongliang, S.; Martinez-Ayala, A. L. \& Trakhtenberg, S. (2003). InterRelationship between Electrophoretic Characteristics of Pseudocereal and Cereal Proteins and Their Microscopic Structure for Possible Substitution Based on Nutritional Evaluation. International Journal of Food Sciences and Nutrition 54 (6), pp. 427- 435, ISSN 1465-3478

Gorinstein, S.; Pawelzik, E.; Delgado-Licon, E.; Yamamoto, K.; Kobayashi, S.; Taniguchi, H.; Haruenkit, R.; Park, Y.; Jung, S.; Drzewiecki, J. \& Trakhtenberg, S. (2004). Use of scanning electron microscopy to indicate the similarities and differences in pseudocereal and cereal proteins. International Journal of Food Science and Technology, 39, pp. 183-189, ISSN 0950-5423

Gorinstein, S.; Drzewiecki, J.; Delgado, E.; Pawelzik, E.; Martinez-Ayala, A. L.; Medina, O. J.; Haruenkit, R. \& Trakhtenberg, S. (2005). Relationship between dicotyledoneamaranth, quinoa, fagopyrum, soybean and monocots- sorghum and rice based on protein analyses and their used as substitution of each other. European Food Research and Technology, 221, pp. 69-77, ISSN 1438-2377

Hanelt, P. \& Institute of Plant Genetics and Crop Plant Research (IPGCPR) (Eds.) (2001). Mansfeld's Encyclopedia of Agricultural and Horticultural Crops. 1-6, 3716 pp. ISBN: 978-3-540-41017-1, Berlin, Germany

'The International Plant Names Index' (IPNI) (2008). Available on the Internet http:/ / www.ipni.org [accessed 22 August 2011].

Iqbal, S. M.; Ghafoor, A. \& Ayub N. (2005). Relationship between SDS-PAGE Markers and Ascochyta Blight in Chickpea. Pakistan Journal of Botany 37 (1), pp. 87-96, ISSN 05563321

Jaramillo, S. \& Baena M. (2002). Ex situ conservation of plant genetic resources: training module. International Plant Genetic Resources Institute, ISBN 978-92-9043-751-2, Cali, Colombia.

Jarošová, J.; Michalová, A.; Vavreinová, S. \& Moudrý, J. (1997). Cultivation and utilization of amaranth. UZPI Praha, ISBN 80-7271-042-7. (in Czech)

Juan, R.; Pastor, J.; Alai, M. \& Vioque, J. (2007). Electrophoretic characterization of Amaranthus L. seed proteins and its systematic implications. Botanical Journal of the Linnean Society, 155, pp. 57-63, ISSN 0024-4074 
Jugran, A.; Bhatt, I. D. \& Rawal, R. S. (2010). Characterisation of Agro-diversity by Seed Storage Protein Electrophoresis: Focus on Rice Germplasm from Uttarakhand Himalaya, India. Rice Science, 17 (2), pp. 122-128, ISSN1672-6308

Kaul, H. E.; Aufhammer, W.; Laible, B; Nalborczyk, E.; Pirog, S. \& Wasiak, K. (1996). The suitability of amaranth genotypes for grain and fodder use in Central Europe. Die Bodenkultur, 47 (3), pp. 173 - 181, ISSN 0006-5471

Laemmli U. K. (1970). Cleavage of Structural Proteins during the Assembly of the Head of Bacteriophage T4. Nature 227 (5259), pp. 608-685, ISSN 0028-0836

Marcone, M. F. (2002). A non-DNA-based marker technique to differentiate between Amaranthus pumilus (a federally protected, threatened plant species) from among more common amaranth cultivars. Journal of Food Composition and Analysis, 15, pp. 115-119, ISSN 0889-1575

Michalova, A. (1999). Amaranthus L. Vyziva a potravinarstvi 54, pp. 13-14 (in Czech)

Moudry, J.; Pejcha, J. \& Peterka, J. (1999). The effect of genotype and farming technology on the yield of amaranth Amaranthus sp. Collection of Scientific Papers, Faculty of Agriculture in ČeskeBudujovice, Series for Crop Sciences 16, pp. 93-98. (in Czech)

National Research Council (NRC) (1984). Amaranth: Modern Prospects for an Ancient Crop. National Academy Press, Washington, DC.80 pp.

Osborne T. B. (1907). The Proteins of the Wheat Kernel. Carnegie Institution of Washington, Washington: 119 pp.

Petr, J. ; J.; Michalik, I.; Tlaskalova, H.; Capouchova, I.; Famera, O.; Urminska, D.; Tuckova, L. \& Knoblochova, H. (2003). Extention of the Spectra of Plant Products for the Diet in Coeliac Disease. Czech Journal of Food Science, 21 (2), pp. 59-70, ISSN 1212-1800

Pisarikova, B.; Zraly, Z.; Kracmar, S.; Trckova, M. \& Herzig, I. (2005). Nutritive value of amaranth grain (Amaranthus L.) in the diets for broiler chickens. Czech Journal of Animal Science, 50, pp. 568-573, ISSN 1212-1819

T. \& Roy, S. C. (2009). Genetic Diversity of Amaranthus Species from the Indo-Gangetic Plains Revealed by RAPD Analysis Leading to the Development of EcotypeSpecific SCAR Marker. Journal of Heredity 100 (3), pp. 338-347, ISSN 1465-7333

Rayburn, A. L.; McCloskey, R.; Tatum, T. C.; Bollero, G. A.; Jeschke, M. R.; \& Tranel, P. J. (2005). Genome Size Analysis of Weedy Amaranthus Species. Crop Science, 45, pp. 2557-2562, ISSN 1435-0653

Segura-Nieto, M.; Barba de la Rosa, A. P. \& Paredes-Lopez, O. (1994). Biochemistry of Amaranth Proteins. In: Amaranth: Biology, Chemistry and Technology. Paredes-Lopez O. (Ed.), pp. 76-106. CRC, ISBN 0-8493-5374-2, Boca Raton, USA

Sauer, J. D. (1950). The grain amaranths: a survey of their history and classification. Annals of the Missouri Botanical Garden, 37, pp. 561-619, ISSN0026-6493

Sauer, J. D. (1967). The grain amaranths and their relatives: a revised taxonomic and geographic survey. Annals of MissouriBotanical Garden, 54, pp. 103-137, ISSN00266493

Sangameswaran, B. \& Jayakar, B. (2008). Anti-diabetic, anti-hyperlipidemic and spermatogenic effects of Amaranthus spinosus Linn. onstreptozotocin-induced diabetic rats. Journal of natural medicines, 62, pp. 79-82, ISSN 1340-3443

Smith, D. B. \& Simpson P. A. (1983): Relationships of barley proteins soluble in sodium dodecyl sulphate to malting quality and varietal identification. Journal of Cereal Science. 1, 185-197, ISSN0733-5210 
Srivastava, S. \& Gupta, P. S. (2002). SDS and Native Page Protein Profile for Identification and Characterization of Elite Sugarcane Genotypes. Sugar Technology 4 (3), pp. 143147, ISSN 0972-1525

Standley P. C. \& Steyermark J. A. (1946): Flora of Guatemala. Series: Fieldiana: Botany 24 (4). 152 -157. Chicago, USA

Tironi, V. A. \& Añón, M. C. (2010). Amaranth proteins as a source of antioxidant peptides: Effect of proteolysis. Food Research International 43, pp. 315-322, ISSN 0963-9969

Thanapornpoonpong, S.; Vearasilp, S.; Pawelzik, E. \& Gorinstein, S. (2008). Influence of Various Nitrogen Applications on Protein and Amino Acid Profiles of Amaranth and Quinoa. Journal of Agricultural and Food Chemistry, 56, pp. 11464-11470, ISSN 1520-5118

Transue, D. K.; Fairbanks, D. J.; Robison, L. R. \& Andersen W. R. (1994). Species Identification by RAPD Analysis of Grain Amaranth Genetic Resources. Crop Science 34: 1385 - 1389, ISSN: 1435-0653

Vasco-Mendez, N. L. \& Paredes-Lopez, O. (1995). Antigenic homology between Amaranth glutelins and other storage proteins. Journal of Food Biochemistry, 18 (4), pp. 227-238, ISSN 0145-8884

Vaz, A. C.; Pinheiro, C.; Martins, J. M. N. \& Ricardo, C. P. P. (2004). Cultivar discrimination of Portuguese Lupinusalbus by seed protein electrophoresis: the importance of considering "glutelins" and glycoproteins. Field Crops Research. 87, 23-34, ISSN 0378-4290

Xu, F. \& Sun, M. (2001). Comparative Analysis of Phylogenetic Relationships of Grain Amaranths and Their Wild Relatives (Amaranthus; Amaranthaceae) Using Internal Transcribed Spacer, Amplified Fragment Length Polymorphism, and DoublePrimer Fluorescent Intersimple Sequence Repeat Markers. Molecular Phylogenetics and Evolution 21 (3), pp. 372-387, ISSN1055-7903

Watson, S. (1877). Contributions to American Botany. VII. Descriptions of New Species of Plants, with Revisions of Lychnis, Erigonum, and Chorizanthe. Proceeding of American Academy of Arts and Sciences, 12, pp. 246-278

H.; Sun, M.; Yue, S.; Sun, H.; Cai, Y.; Huang, R.; Brenner D. \& Corke, H. (2000). Field Evaluation of an Amaranthus Genetic Resource Collection in China. Genetic Resources and Crop Evolution 47 (1), pp. 43-53, ISSN 1573-5109

Zheleznov, A. V.; Solonenko, L. P. \& Zheleznova, N. B. (1997). Seed proteins of the wild and the cultivated Amaranthus species. Euphytica, 97 (2), pp. 177-182, ISSN 00142336 


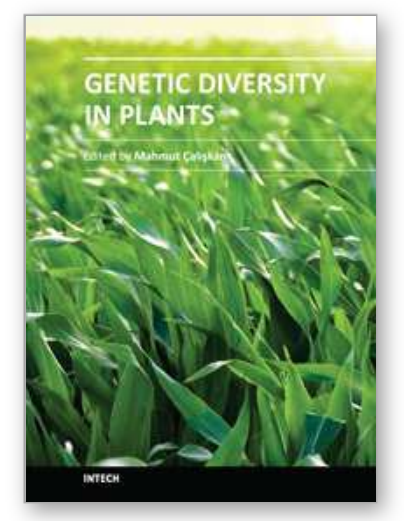

\author{
Genetic Diversity in Plants \\ Edited by Prof. Mahmut Caliskan
}

ISBN 978-953-51-0185-7

Hard cover, 498 pages

Publisher InTech

Published online 14, March, 2012

Published in print edition March, 2012

Genetic diversity is of fundamental importance in the continuity of a species as it provides the necessary adaptation to the prevailing biotic and abiotic environmental conditions, and enables change in the genetic composition to cope with changes in the environment. Genetic Diversity in Plants presents chapters revealing the magnitude of genetic variation existing in plant populations. The increasing availability of PCR-based molecular markers allows the detailed analyses and evaluation of genetic diversity in plants and also, the detection of genes influencing economically important traits. The purpose of the book is to provide a glimpse into the dynamic process of genetic variation by presenting the thoughts of scientists who are engaged in the generation of new ideas and techniques employed for the assessment of genetic diversity, often from very different perspectives. The book should prove useful to students, researchers, and experts in the area of conservation biology, genetic diversity, and molecular biology.

\title{
How to reference
}

In order to correctly reference this scholarly work, feel free to copy and paste the following:

Dagmar Janovská, Petra Hlásná Čepková and Mária Džunková (2012). Characterisation of the Amaranth Genetic Resources in the Czech Gene Bank, Genetic Diversity in Plants, Prof. Mahmut Caliskan (Ed.), ISBN: 978-953-51-0185-7, InTech, Available from: http://www.intechopen.com/books/genetic-diversity-inplants/characterisation-of-the-amaranth-genetic-resources-in-the-czech-gene-bank

\section{INTECH}

open science | open minds

\author{
InTech Europe \\ University Campus STeP Ri \\ Slavka Krautzeka 83/A \\ 51000 Rijeka, Croatia \\ Phone: +385 (51) 770447 \\ Fax: +385 (51) 686166 \\ www.intechopen.com
}

\author{
InTech China \\ Unit 405, Office Block, Hotel Equatorial Shanghai \\ No.65, Yan An Road (West), Shanghai, 200040, China \\ 中国上海市延安西路65号上海国际贵都大饭店办公楼 405 单元 \\ Phone: +86-21-62489820 \\ Fax: $+86-21-62489821$
}


(C) 2012 The Author(s). Licensee IntechOpen. This is an open access article distributed under the terms of the Creative Commons Attribution 3.0 License, which permits unrestricted use, distribution, and reproduction in any medium, provided the original work is properly cited. 